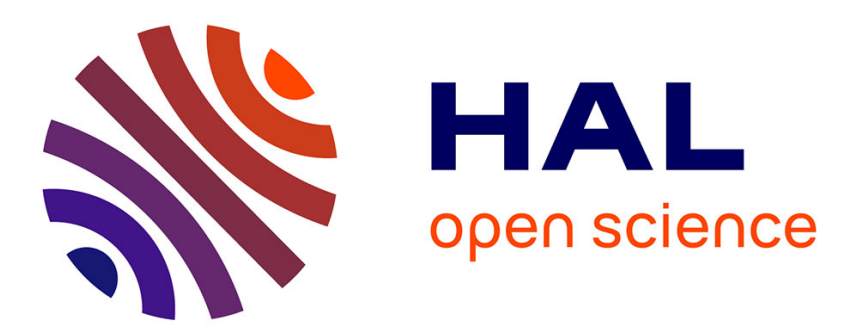

\title{
Managing country-of-origin affiliations for luxury brand-building in China
}

Klaus Heine, Glyn Atwal, Jiaxun He

\section{To cite this version:}

Klaus Heine, Glyn Atwal, Jiaxun He. Managing country-of-origin affiliations for luxury brand-building in China. AMJ, Australasian Marketing Journal, 2019, 27 (1), 14-23 p. hal-02312231

\section{HAL Id: hal-02312231 \\ https://hal.science/hal-02312231}

Submitted on 22 Oct 2021

HAL is a multi-disciplinary open access archive for the deposit and dissemination of scientific research documents, whether they are published or not. The documents may come from teaching and research institutions in France or abroad, or from public or private research centers.
L'archive ouverte pluridisciplinaire HAL, est destinée au dépôt et à la diffusion de documents scientifiques de niveau recherche, publiés ou non, émanant des établissements d'enseignement et de recherche français ou étrangers, des laboratoires publics ou privés.

\section{다)(1) $(5$}

Distributed under a Creative Commons Attribution - NonCommercial| 4.0 International 


\title{
MANAGING COUNTRY-OF-ORIGIN AFFILIATIONS \\ FOR LUXURY BRAND-BUILDING IN CHINA
}

\author{
Klaus HEINE* \\ EMLYON Business School \\ 2/F, Global Education Centre, East China Normal University \\ No. 3663 North Zhongshan Road, Shanghai 200062, China \\ heine@em-lyon.com \\ +86-(21)-62.60.71.54 ext. 815
}

Glyn ATWAL

Burgundy School of Business

29 Rue Sambin, 21000 Dijon, France

glyn.atwal@bsb-education.com

+33380725900

\begin{abstract}
Jiaxun HE
East China Normal University / Dean of the Asia Europe Business School South Building of Business School, 500 Dongchuan Road, Shanghai, China $+86-(21)-54.34 .49 .58$

jxhe@dbm.ecnu.edu.cn
\end{abstract}

Corresponding author* 


\title{
MANAGING COUNTRY-OF-ORIGIN AFFIIIATIONS \\ FOR LUXURY BRAND-BUILDING IN CHINA
}

\begin{abstract}
The recent wave of luxury ventures in China has created an important need to understand luxury brand-building in China. A critical component of this research domain is the concept of country-of-origin $(\mathrm{CoO})$. Chinese ventures use multiple country associations which makes the country one of the most suitable places to study the new phenomenon of hybrid brands. This marks a new stage in the evolution of $\mathrm{CoO}$ research. Findings stemming from a conceptual research and an explorative study are used to develop a conceptual model for managing $\mathrm{CoO}$ affiliations for hybrid brands within the context of Chinese luxury brands. Practical implications will help brand managers to understand which $\mathrm{CoO}$ facets make a luxury brand 'Chinese' and, on the other hand, how to improve brand prestige with Western $\mathrm{CoO}$ cues.
\end{abstract}

Key words: luxury brands, brand-building, country-of-origin, country-of-origin-of-brand, China 


\section{Introduction}

The Chinese luxury market is set to embark on a new era. As the government seeks to move the country up the global value chain, the recent Five Year Plan requires China's economic orientation to shift from low-end production to higher-end and creative industries (NDRC, 2016). Consumers and marketers in China had strongly believed in the basic principle: Western stuff is hot - and Chinese stuff is not (O'Cass and Siahtiri, 2013). Until recently, studies underlined that consumer ethnocentricity in China was relatively low and did not translate into preferences for Chinese products (Tsai et al., 2013). However, the 'young emperors', the generation born after 1978, is reviving an interest and appreciation in national culture and traditions which is consistent with a growing interest in Chinese luxury brands (He and Wang, 2015).

Chinese executives and entrepreneurs are not only motivated to create luxury brands for profit but also because of their strong fascination for luxury and even to instill a sense of pride in their companies and country. There has been a global growth of luxury business start-ups which has accelerated since the 1990s along with the upswing of the global luxury market (Heine and Phan, 2011). This has given rise to a variety of Western and Chinese market players setting-up Chinese luxury brands such as Qeelin jewelry (created by a French entrepreneur), Changyu wine (partly acquired by Illva Saronno) and Shanghai Vive (created by government-owned Shanghai Jahwa group).

Apart from empirical studies on corporate brand-building (Juntunen et al., 2010), there is a limited number of studies about luxury brand-building (Beverland, 2005), the related area of luxury marketing success factors (Fionda and Moore, 2008) and luxury entrepreneurship (Fonrouge and Lipovetsky, 2013). Significantly, the literature on luxury marketing in China tends to concentrate on consumer behavior (Chadha and Husband, 2006; Walley and Li, 2014; Zhan and He, 2012) and to a lesser extent on the expansion of Western luxury brands into the Chinese market (Atwal and Bryson, 2017; Chevalier and Lu, 2010; Gao et al., 2009). The lack of research about the creation of luxury brands in China represents an important gap within the literature in light of the increasing number of Chinese luxury brands in recent years.

As the bias against products from emerging countries was found to be of significant relevance within the luxury segment (Cordell, 1991; Manrai at al., 1998), country-of-origin (CoO) 
considerations belong to the most critical factors for luxury brand-building in China. Chinese and foreign luxury entrepreneurs are torn between the traditional paradigm of 'Western stuff is hot' and the increasing interest in Chinese traditions. Chinese entrepreneurs aim to establish truly Chinese brands to benefit from current societal trends. However, there is also a need for many brandbuilders to symbolize that their luxury brand is not 'only Chinese' by linking their brand with foreign $\mathrm{CoO}$ cues (e.g. manufacturing in Italy) with the objective to strengthen brand prestige. Foreign entrepreneurs are facing the challenge to make their luxury brand perceived as being Chinese, but on the other hand, they are inclined to seduce Chinese consumers by evoking associations with their Western home countries, which may in turn reduce their brand's Chineseness. As a result, a host of new hybrid brands are emerging in the Chinese luxury market which combine multiple country associations.

Our objective is to develop a conceptual model for managing $\mathrm{CoO}$ affiliations for Chinese luxury brands. We identified the following research objectives:

- Research objective 1 . We seek to define hybrid products and brands (see subsequent section) and differentiate between various types of hybrid brands. After placing our topic into the context of existing CoO-related research (section 3.1), we attempt to resolve the vast complexity of Country-of-Brand affiliations with the conceptualization of the Country-of-origin-of-Brand ( $\mathrm{CoB}$; section 3.3.) and by splitting the $\mathrm{CoB}$ into major components (section 3.4).

- Research objective 2. What makes a luxury brand Chinese? On the basis of an extensive literature review, we decompose the $\mathrm{CoO}$ concept into multiple facets (section 3.2). A study in China sets out to identify $\mathrm{CoB}$ dimensions which consumers use to evaluate a luxury brand's Chineseness.

- Research objective 3. What are foreign $\mathrm{CoO}$ cues a Chinese luxury brand can leverage? As brand prestige in China is related to brand internationality (Chahal and Dutta, 2012), we identify $\mathrm{CoO}$ facets that might be useful for Chinese luxury brands to signal brand internationality (section 3.5.).

- Research objective 4. Based on existing literature and an empirical study in China, we explore effective strategies for Chinese luxury brands to communicate CoB cues. 


\section{What are Hybrid Products and Brands?}

When CoO research started in the 1960s with studies about the existence and consequences of CoO effects (Schooler, 1965), the largest share of a product's manufacturing process still took place in the manufacturer's home country. This did not really change in the second phase of $\mathrm{CoO}$ research in the 1980s, which was initiated by a call for multi-cue studies. Researchers sought to resemble more complex and thus more realistic consumer purchasing conditions by measuring $\mathrm{CoO}$ effects with reference to multiple variables such as price, performance, and warranty, (Bilkey and Nes, 1982; Wall et al., 1991). However, the third phase of $\mathrm{CoO}$ research was driven by the globalization of production chains and the emergence of hybrid products. Hybrid products are defined as products with multiple country-of-origin affiliations as a result of the efforts of multinational enterprises in distributing various aspects of the value chain (such as design and manufacturing) in different locations worldwide (Chao, 1993). A prototypical example is Apple's iPhone which is 'Designed in California' and assembled by Foxconn in China with key components supplied by Japan and South Korea. Research about hybrid products took off in the 1990s with numerous studies about the impact of different origins of hybrid products on product evaluations (e.g. Ahmed and d'Astous, 1993; Lee and Bae, 1999).

While complex products with multiple country affiliations have become much more common, the research paradigm in the third phase of $\mathrm{CoC}$ research still assumed that a brand would typically be tied to a single country-of-origin. But with globalization rapidly advancing, there is a trend to associate brands with multiple country affiliations. This can be observed in the start-up scene in China and by Chinese entrepreneurs abroad. For example, Chinese-born designer Yiqing Yin created a Paris-based brand inspired by her national identity; British-born Alison M.C. Yeung established Mary Ching as an Anglo-Chinese luxury brand, and non-Chinese designers such as Charles Philip have set up luxury brands in China. As a reflection of the recent structural changes in the global business environment, the fourth phase of $\mathrm{CoO}$ research may be initiated by the emergence of hybrid brands. Within the context of $\mathrm{CoO}$ research, hybrid brands can be defined as brands that are integrating $\mathrm{CoO}$ affiliations to more than one country into their brand identify.

Godart and Zhao (2014) introduced the notion of brand hybridity. The authors argue that lowhybridity brands draw their inspiration mainly from one country and high-hybridity brands are characterized by a mix of elements of two or more cultures into a multi-cultural brand identity. Qeelin is a typical low-hybridity brand with an emphasis on Chineseness with country-specific symbols in its jewelery designs combined with an association with its foreign founders and owners. 
London-born designer Beatrix Ong adopts a medium-hybridity strategy by focusing the positioning of the brand on sustainability, but still drawing inspiration from her Chinese family traditions. As a typical representative of the high-hybridity category, London-based designer Huishan Zhang displays his collections as being integral to the 'East meets West' brand theme. Godart and Zhao (2014) argue that a hybrid brand strategy may appeal to a wider audience, but may also restrain brand authenticity.

\section{The CoO Concept}

\subsection{Placing the $\mathrm{CoO}$ concept into the context of $\mathrm{CoO}$-related research}

The area of research on $\mathrm{CoO}$ effects is diverse and complex. Distinguishing the major areas of $\mathrm{CoO}$ research sets to limit the scope of our research and to place it into the overall context of $\mathrm{CoO}$ research (see Figure 1). One of the major $\mathrm{CoO}$ research fields concentrates on the impact of consumer characteristics on $\mathrm{CoO}$ effects including (1) socio-demographics (Usunier, 1994), (2) cultural differences (Ahmed and d'Astous, 2008), and (3) personality traits such as ethnocentrism (Han and Terpstra, 1988). Another research stream is dealing with the impact of country characteristics on $\mathrm{CoO}$ effects including studies on country image dimensions (Roth and Romeo, 1992) or cultural, social, and political factors (Ahmed and d'Astous, 2008; Usunier, 1994). A further focal area of $\mathrm{CoO}$ research deals with the impact of product / brand characteristics on $\mathrm{CoO}$ effects which includes studies analyzing $\mathrm{CoO}$ effects depending on, for instance, the product category (Manrai et al., 1998) and product characteristics such as conspicuousness (Ahmed and d'Astous, 2008; Wall et al., 1991). In addition, there exists a research stream analyzing the $\mathrm{CoO}$ effects, i.e. the consequences of $\mathrm{CoO}$ cues in the consumer decision-making process, for instance, on brand and product evaluations (Wall et al., 1991), purchase, and brand relationship quality (Jung et al., 2014).

In this paper we concentrate on the research stream, the $\mathrm{CoO}$ concept. As a basis for our research, we rely on the conceptual model of Phau and Prendergast (2000), which is reflected in the classification of the $\mathrm{CoO}$ components as shown in Figure 1. This research stream splits into the following sub-topics, which is consistent with our research objectives and will be covered in the following sections: 
- Country-of-origin-of-Brand $(\mathrm{CoB})$. This research stream addresses the conceptualization of the $\mathrm{CoB}$ construct and its relevance in consumer decision-making (Ahmed and d'Astous, 2008; Manrai et al., 1998; Phau and Prendergast, 2000; see section 3.3).

- Dimensions of CoO. This research stream refers to the 'decomposition' of the CoO construct into various facets, the interrelations between them and their impact on consumer response (Ahmed and D'Astous, 1993; Bloemer et al., 2009; Chao, 1993; Jung et al., 2014).

- Communication of $\mathrm{CoO}$ cues to consumers. This includes research about the means of communication of $\mathrm{CoO}$ cues, such as the brand name or packaging (Phau and Prendergast, 2000), the processing of CoO-information (Bloemer et al., 2009), and about how consumers use multiple cues to evaluate brand origin (Cheah et al., 2016).

Fig. 1. The major areas of $\mathrm{CoO}$ research

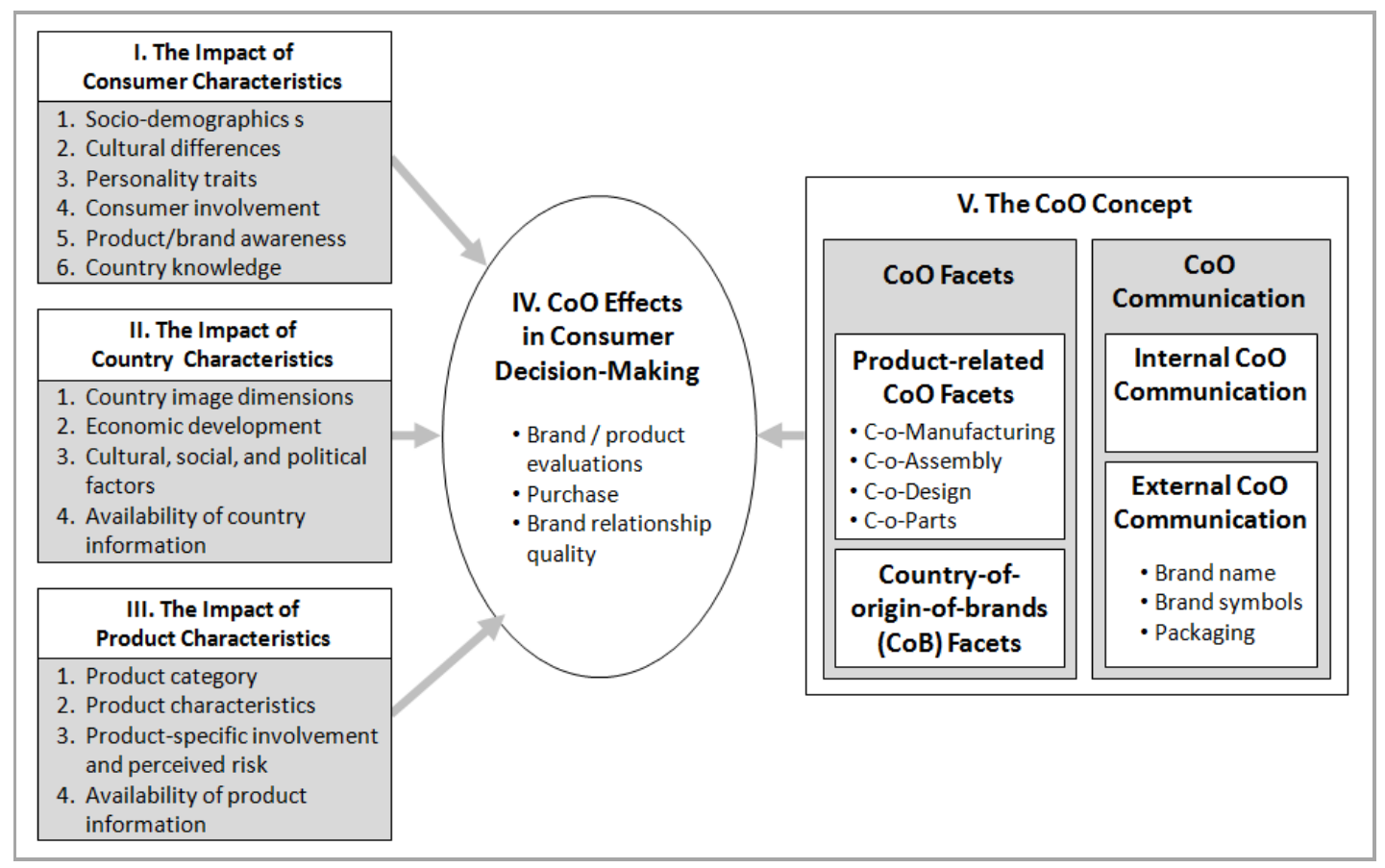

\subsection{Decomposing the CoO concept into multiple facets}

The globalization of production chains and the emergence of hybrid products in the third phase of $\mathrm{CoO}$ research has been critical to the $\mathrm{CoO}$ concept. As a consequence, the $\mathrm{CoO}$ concept was identified as a multi-dimensional 'umbrella' concept that integrates multiple facets of $\mathrm{CoO}$ (Balabanis and Diamantopulos, 2008; Kipnis et al., 2012). Researchers distinguished the following product-related $\mathrm{CoO}$ facets: Country-of-Manufacturing (CoM) or Country-of-Assembly (CoA), Country-of-Design (CoD; Jung et al, 2014); "Parts supplied by" / Country-of-Parts (COP; Kipnis et 
al., 2012), Country-of-Ingredients (Cheah et al., 2016), and "Engineered in" (Chao, 1993). This provides a framework for the analysis of $\mathrm{CoO}$ facets which luxury brand managers in China can use to make their brands appear more international.

As a reaction to the emergence of hybrid products, Phau and Prendergast (2000) distinguished between the $\mathrm{CoO}$ of products and the country-of-origin-of-brands $(\mathrm{CoB})$. As international integration accelerates, consumers may not evaluate, not know or just confuse the different origins of hybrid products (Balabanis and Diamantopoulos, 2008). Therefore, Phau and Prendergast (2000) expect consumers to rely more on the $\mathrm{CoO}$ image of brands and to perceive the $\mathrm{CoB}$ as independent from changes in manufacturing locations. In addition, changes in the product-related $\mathrm{CoO}$ concepts have an impact on the consumer's perception of the brand image. For instance, brand quality image tends to decline when CoM is moved to less-developed countries, but can be improved by marketing efforts stressing a reputable country of design (Phau and Prendergast, 2000).

However, $\mathrm{CoO}$ remains a controversial research field with many studies reporting inconsistent and even contradictory findings (Godey et al., 2013), especially in regard to multi-cue studies about hybrid products (Miyazaki et al., 2005). For instance, some studies found that the $\mathrm{CoO}$ effect is increasing with consumer involvement (Hugstad and Durr, 1986), while other studies assert the opposite (Manrai et al., 1998; Prendergast et al., 2010). The inconsistent results can be explained partly by the fact that the consumer's $\mathrm{CoO}$ perceptions are changing over time. However, inconsistencies in research studies may also relate to misunderstandings about the conceptualization of CoB (see also Bloemer et al., 2009). During the second stage of CoO research, Johansson et al. (1985, p. 389) had still defined $\mathrm{CoO}$ as "the country where the corporate headquarter of the company marketing the product or brand is located" which suggests that country of origin is actually reflected as the $\mathrm{CoB}$ of the product. However, Phau and Prendergast (2000) point out that many researchers do not provide a coherent conceptualization of $\mathrm{CoO}$, and may not take the concept of $\mathrm{CoB}$ into account, but still pursue the traditional research paradigm of $\mathrm{CoO}$ as the country-of-manufacture. There are many brands such as Gucci or Hermès which consumers can spontaneously recognize their origins; other brands such as Donna Karen New York explicitly carry the location of their origin in their names. It can therefore be observed that merely manipulating the different dimensions of the $\mathrm{CoO}$ construct does not eliminate the effects of these cues and can reduce the validity of results. Therefore, the following section defines the concept of CoB with the objective to underpin a theoretical understanding. This in turn will reduce potential misunderstandings and inconsistencies in $\mathrm{CoO}$ research. 


\subsection{The Country-of-origin-of-Brand}

Studies show that consumers take various $\mathrm{CoO}$ facets such as $\mathrm{CoM}$ and $\mathrm{CoD}$ into account for product evaluations, but $\mathrm{CoB}$ tends to have a greater impact on purchase intentions (Ahmed and d'Astous, 2008; Manrai et al., 1998). Generally, the CoB was seen as where the brand's headquarters are located and the major management and marketing activities are performed, regardless of where the products are manufactured (Balabanis and Diamantopulos, 2008; Phau and Prendergast, 2000). However, this still leaves some room for misunderstanding. For instance, Gucci had moved its official tax-relevant headquarters to the Netherlands, but kept its positioning as an Italian brand. Godiva is positioned as a Belgian luxury chocolate brand, but, as stated on its website, world headquarters with major management and marketing operations are in fact located in New York. The inconsistencies in the conceptualization of CoB may be related to the traditional research paradigm in the area of $\mathrm{CoO}$ research.

Traditionally, $\mathrm{CoO}$ research relies on the theory of information cues which presumes that consumers cannot adequately assess product quality directly and therefore use other cues (also "signs") such as price, packaging style or labeling to assist in evaluating products (Wall et al., 1991). Researchers distinguish between intrinsic and extrinsic cues. Intrinsic cues are product attributes inherent to the product that cannot be changed without changing the physical product characteristics, for instance, the color or taste of wine. Extrinsic cues refer to the product's nonphysical characteristics such as price, place of purchase, and brand image including country-oforigin information (Olson and Jacoby, 1972). CoO cues include the brand name, visual imagery, and 'made in' labeling (Kipnis et al., 2012). Information cue theory suggests that a favorable country image (e.g. Germany's strength in engineering) has a positive impact on the quality evaluations of products from this country (such as BMW cars) which increases the likelihood of purchase. Most of the existing consumer research concentrates on the use of $\mathrm{CoO}$ information to evaluate product quality which reflects a still very product-oriented $\mathrm{CoO}$ understanding. Research indicates that consumers consider the place of manufacture and the brand's $\mathrm{CoO}$ attributes in their purchase decisions (Häubl and Elrod, 1999). It is within this context that Godey et al. (2012) suggest that $\mathrm{CoO}$ research needs to consider the brand as a key driver in the consumer's decisionmaking process (see also Jung et al., 2014). In recent decades, competitive advantage has shifted from functional to symbolic benefits that enable consumers to express their own self-image (Liu et al., 2012). For instance, although it is widely accepted that the product quality of BMW is superior, some consumers may still decide to purchase an Alfa Romeo because of their enthusiasm for Italian dolce vita. This suggests that the traditional approach of studying the effects of $\mathrm{CoO}$ information as 
extrinsic cues on product quality evaluation may no longer be adequate to fully understand $\mathrm{CoO}$ effects. We therefore suggest reducing inconsistencies with the help of self-concept theory and by considering the $\mathrm{CoB}$ as a vital component of brand identity.

Self-concept theory provides a major explanation for (luxury) consumption and helps to explain purchase decisions with symbolic benefits (such as BMW's prestige or other brand personality traits), but has not been integrated into the conceptualization of CoB. Self-concept is a general term used to refer to how a person evaluates or perceives him- or herself. Research has identified major aspects of the human self-concept including the actual self (how people perceive themselves), the social self (how people feel others see them) and the ideal social self (how people would like others to see them; Sirgy et al., 2008). Applied to brands, the brand image can be compared with the social self (how the brand is perceived by its target groups) and the brand identity refers to the ideal social self (how the brand would like to be perceived by its target groups). Driven by basic human needs, people are either trying to preserve their self-concept via self-consistency motivation or enhance their self-concept via self-esteem motivation (Hong and Zinkhan, 1995). Self-congruity theory suggests that the more a brand's symbolic meaning is congruent with the consumer's own (ideal) self-concept, the more they use the brand to communicate their self (Hong and Zinkhan, 1995). Individuals are motivated to reduce the gap between their actual and ideal selves through purchasing products and brands that symbolically represent their ideal self (Mittal, 2006). As a

result, consumers are less drawn to brands that have minimal relevance to their self-concept, but rather to aspirational brands (e.g. luxury brands) that are associated with (ideal) personality characteristics and reference groups that are respected or valued within their (sub-) culture (Ward and Dahl, 2014). For instance, consumers may purchase a Hermès bag to improve and signal their social status. As luxury brands are especially relevant for impression management, there exists a wealth of research on self-concept theory in luxury consumption (e.g. Gil et al., 2012, Ward and Dahl, 2014). The next section applies the self-concept theory to the CoB concept.

\subsection{Managing the $\mathrm{CoB}$ identity}

$\mathrm{CoB}$ can be regarded as a vital component of a brand's identity and more precisely, as part of the culture facet in the brand identity prism as developed by Kapferer (2012). With reference to selfconcept theory, we suggest to differentiate between the actual $\mathrm{CoB}$ identity (actual country affiliations), the desired $\mathrm{CoB}$ identity (countries the brand wants to be affiliated with) and the $\mathrm{CoB}$ image. In contrast to what a company would like to make consumers believe by its brand communications, the $\mathrm{CoB}$ image (the brand's actual social self) covers which country or countries 
consumers actually believe the brand is affiliated with - and this is what matters most for consumer decision making (Magnussson et al., 2011).

Just as people can hardly modify some of their given characteristics such as biological age or body height, brand managers have to deal with some actual and possibly unchangeable strands of the brand's DNA. The actual $\mathrm{CoB}$ identity includes, for instance, the official location of the headquarters (for strategic, historic or tax reasons) or the countries of production (for financial reasons). The major component of the (desired) $\mathrm{CoB}$ identity is brand nationality (c.f. Orbaiz and Papadopoulos, 2003; see Figure 2). Brand nationality reflects the deliberate decision of brand managers about what should be internally and externally considered as the brand's home country and culture (e.g. Belgium in the case of Godiva). Just like people who may perceive themselves as Chinese, British-Chinese, European or even as global citizens, brand managers can decide for a single-country identity, a (multi-cultural) hybrid identity, or a cosmopolitan identity. For instance, many French brands such as Hermès have a strong national CoB identity, whereas managers of Montblanc may perceive their brand as being European or cosmopolitan, while its actual CoB is German and, because of its brand name, its $\mathrm{CoB}$ image is French in the eyes of many consumers. The single-country strategy generally refers to indigenous brands based in their actual home country. By using a foreign branding strategy, companies set out to actively conceal their true origin and associate their brand with a favorable culture through a foreign-sounding name or other brand symbols. Examples include Häagen-Dazs and many Chinese fashion brands with French or Italianstyled names such as La Chapelle or Ochirly. However, this strategy can backfire if consumers detect the incongruence between actual and desired CoB (Melnyk et al., 2012). 
Fig 2. $\mathrm{CoB}$ components and brand types

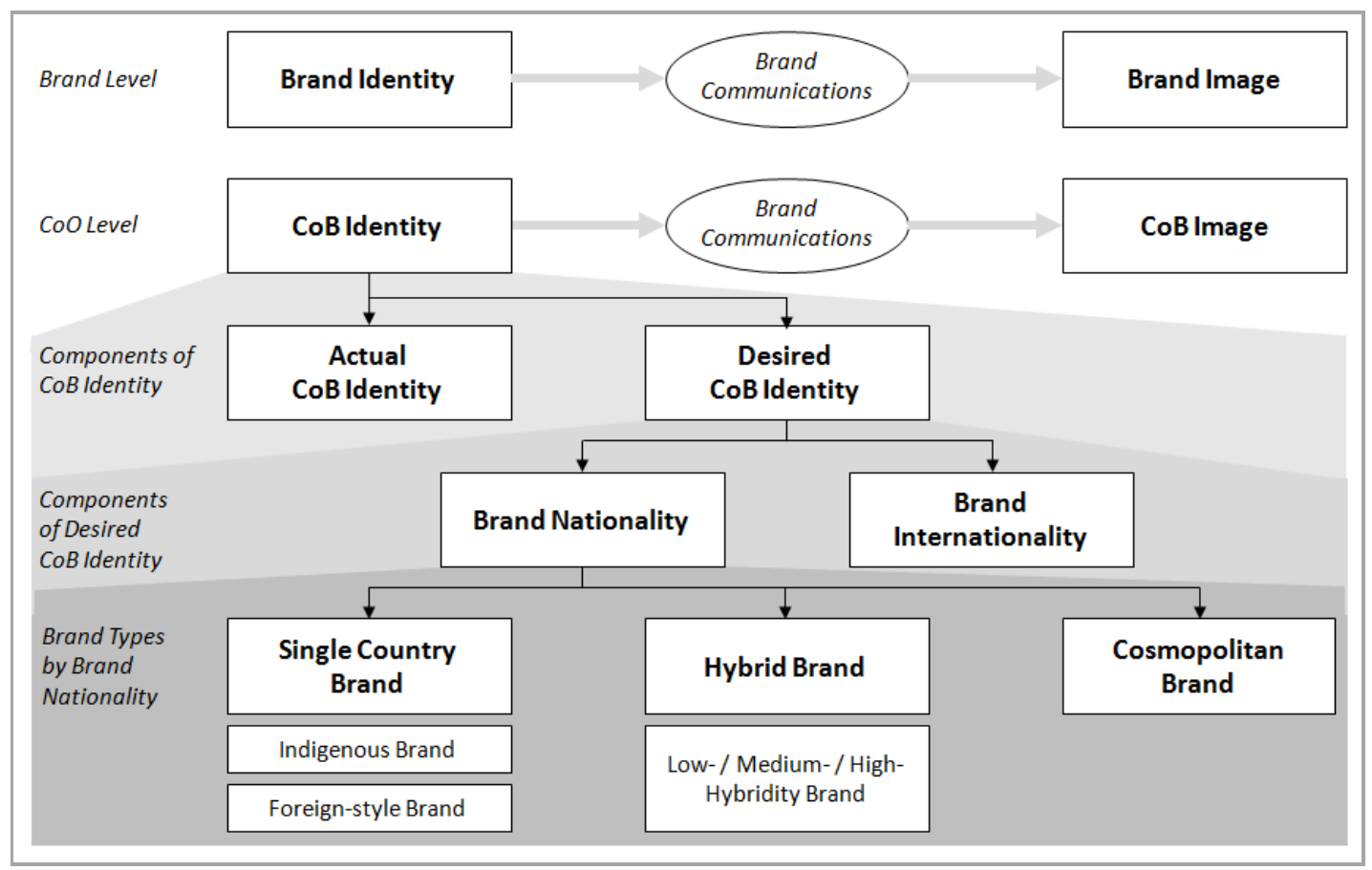

\subsection{Signaling brand internationality}

Another component of the (desired) $\mathrm{CoB}$ identity is brand internationality which refers to the degree managers want their brands to be seen as cosmopolitan. Brand internationality can create affective value by signaling social status and modernity (Kipnis et al., 2012). Particularly in countries with a relatively low $\mathrm{CoO}$ image, brand internationality can be understood as a criterion of brand strength (Chahal and Dutta, 2012). For Chinese luxury brands, brand internationality remains a key success factor, as long as their $\mathrm{CoB}$ image is not on the level of their Western competitors. Knowing that a French man or woman remains French when moving abroad, the same applies to brands. According to the principles of identity-driven brand management, (French) luxury brands do not generally change their (national) identity in foreign markets, also when they manufacture abroad (Kapferer, 2012). But just as a Frenchman or woman may tell others about his/her trips abroad to improve his/her self-concept, brand managers can play with additional country affiliations to upgrade their $\mathrm{CoB}$ image (e.g. by ingredient branding with imported components). For this purpose, luxury brand managers in China need to understand the relevant facets of brand internationality and how to make use of them within the Chinese luxury market (which we address in our empirical study). 
To summarise, $\mathrm{CoB}$ can be defined as the country or countries where target consumers believe a brand originates from ( $\mathrm{CoB}$ image). The example of Godiva demonstrates that the actual $\mathrm{CoB}$ characteristics such as the location of the brand's headquarters do not necessarily play a major role in creating a $\mathrm{CoB}$ identity and image. Based on strategic brand management considerations, marketers need to take a deliberate decision about the country or countries they want their target consumers to believe their brand is from (the $\mathrm{CoB}$ identity), and then make use of brand communications to align their desired $\mathrm{CoB}$ with the actual $\mathrm{CoB}$ image in the minds of their target groups. Our categorization of the $\mathrm{CoB}$ concept is illustrated in Figure 2. The subsequent section explores the existing research on $\mathrm{CoO}$ effects in the luxury segment.

\section{CoO Research in the Luxury Segment}

Although Phau and Prendergast (2000) had called for more research on CoO in luxury over a decade ago, there is still a paucity of research (Arora et al. 2015; Jung et al., 2014). This is surprising given that brand origin is generally seen in the luxury segment as contributing to brand equity (Jung et al., 2014; Yasin et al., 2007), brand distinctiveness (Yasin et al., 2007) and as a competitive advantage that helps increase trust and demand premium prices (Oetzel and Doh, 2009; Shukla, 2010).

The literature has documented the impact of product characteristics on $\mathrm{CoO}$ effects. Piron (2000) found that $\mathrm{CoO}$ cues have a significant impact on the product evaluation and purchase intention of luxuries such as cars and home theatre systems, whereas there was only a small effect on the evaluation and even no effect on purchase intention of necessities such as toothpaste (see also Godey et al., 2012, 2013; Kim, 2008). Research by Cordell (1991) and Manrai et al. (1998) suggests that $\mathrm{CoO}$ effects are stronger for luxury products as compared to mass-market products. According to Godey et al. (2012), consumers recognize geographic and cultural origin as crucial characteristics of luxury brands. With regard to country characteristics, research has been conducted about the luxury-specific CoO image of different countries (Godey et al., 2013), country image dimensions (Jung et al., 2014), and their impact on consumer response (Arora et al., 2015; Cheah et al., 2016). However, it is our knowledge that no study within the literature has investigated CoB facets and their relevance for luxury brand-building in China.

Most research on luxury concentrates on $\mathrm{CoO}$ effects on product quality perceptions, and thus, relies on information cue theory (Jung et al., 2014; Manrai et al. 1998; Shukla, 2010). Following the 
emergence of the $\mathrm{CoB}$ construct and the implications of self-concept theory, the consequences of $\mathrm{CoO}$ effects can be differentiated according to product (quality) evaluations and brand evaluations. However, luxury brands need to embody certain symbolic characteristics (e.g. authenticity and prestige), which influence consumer brand evaluations (Heine and Petersen, 2015). Instead of taking brand authenticity into account, Manrai et al. (1998) recommend a 'non-country branding' for luxury brands from developing countries to improve perceived product quality. However, if one follows the argument that the authenticity of luxury brands relies to a large extent on their cultural identity and place of origin (Godey et al., 2012), this questions the validity of brands adopting an anonymous 'non-country branding' strategy. $\mathrm{CoO}$ effects on brand prestige are of particular relevance for luxury consumption given that it is driven by prestige-seeking behavior (Shukla, 2010). Belk's (1988) theory of the extended self-concept helps to establish a relationship between brand prestige and consumer ethnocentrism (Cordell, 1991). If we accept that people perceive not only their body, possessions, and friends, but even their home country as part of their extended selfconcept, brands from their home country are more closely associated with their self and therefore generally preferred (Escalas and Bettman, 2005). Ethnocentric consumers may still favor foreign luxury products, but only as long as they expect the consequences of the foreign brand's prestige on their self-concept (self-esteem motivation) to exceed the benefits of ethnocentrism (self-consistency motivation; Hong and Zinkhan, 1995). These examples demonstrate that CoO research in luxury should consider the impact on brand authenticity and prestige as relevant consequences of $\mathrm{CoO}$ effects.

\section{Methodology}

\subsection{Case study Analysis}

We employed a multiple case study methodology according to Fionda and Moore (2008) and He and Balmer (2013) who also relied on grounded theory as a research paradigm in a similar research context (Charmaz, 2014; Corbin and Strauss, 2008). The first stage of our study consisted of a pilot online survey of 20 luxury experts in China, who were asked to list all Chinese luxury brands which they knew. Although many contemporary brands may not meet the Western expectations of luxury, they can be considered as high-end brands in their home market. We identified more than 100 potential Chinese luxury brands. The most well-known Chinese luxury brands included (in order of number of mentions): Shanghai Tang, Shang Xia, NE Tiger, Queelin and Maotai. We selected 25 luxury brands for in-depth analysis (see Table 1) using the following criteria: (1) they can be 
regarded as Chinese, and they should represent (2) the major types of luxury market players (Chinese and non-Chinese) and (3) a variety of luxury product categories.

According to grounded theory, the empirical database was obtained from multiple sources. This included the collection and analysis of documentary material found on the luxury brands' online presence and in the business press (see also Fionda and Moore, 2008; He and Balmer, 2013). Based on the principle of purposeful sampling (Corbin and Strauss, 2008), we also conducted 15 semistructured interviews with sales associates in stores of the selected brands in Shanghai (ten to 20 minutes each; 12 respondents were female). We decided to target sales associates because they gain first hand insights into $\mathrm{CoO}$ preferences of Chinese consumers and may use $\mathrm{CoO}$ cues in their selling techniques. The interviews focused on i) how the $\mathrm{CoB}$ was perceived by the brand representatives and consumers and ii) which foreign $\mathrm{CoO}$ cues sales associates use to improve the brand image. After the interviews, the responses were compiled in an interview protocol. Grounded theory relies on an iterative process of data collection, analysis and theory construction. This process generates insights and confirms, disconfirms, or modifies them until an adequate concept is reached - in this case a conceptual model of $\mathrm{CoO}$ dimensions for luxury brand-building in China (Charmaz, 2014; Corbin and Strauss, 2008).

Table 1: List of selected Chinese luxury brands

\begin{tabular}{|l|l|l|l|l|l|}
\hline Brand Name & Product Category & Headquarter & Brand Name & Product Category & Headquarter \\
\hline 1436 Erdos & Apparel & Shenzhen & Shang Xia* & Apparel & Shanghai \\
\hline Ba Yan Ka La & Cosmetics & Shanghai & Shanghai Vive* & Cosmetics & Shanghai \\
\hline C-Oriental Luxurious & Jewelry & Beijing & She Ji-Sorgere* & Apparel & Beijing \\
\hline Chang Yu* & Wine & Yantai & Sheme & Shoes & Chengdu \\
\hline Charles Philip* & Shoes & Shanghai & Shuijinfang & Spirit & Chengdu \\
\hline Hong Qi & Cars & Changchun & Yue Sai & Cosmetics & Shenzhen \\
\hline Jack Peng & Shoes & Shanghai & ZhaoYi Jade & Jewelry & Beijing \\
\hline Longio & Watches & Shenzhen & Blanc de Chine & Apparel & Hong Kong \\
\hline Mary Ching & Shoes & Shanghai & Carnet & Jewelry & Hong Kong \\
\hline Ne Tiger* & Apparel & Beijing & Osiao* & Cosmetics & Hong Kong \\
\hline Omnialuo & Apparel & Shenzhen & Qeeling* & Jewelry & Hong Kong \\
\hline Panda Cigarettes & Tobacco & Shanghai & Shanghai Tang* & Apparel & Hong Kong \\
\hline Sea Gull* & Watches & Tianjing & & & \\
\hline
\end{tabular}

\subsection{Consumer survey}

Based on literature and case study analysis, we identified a list of criteria that consumers may use to decide if a luxury brand is Chinese. We tested these criteria with a qualitative survey. The sample included 18 participants of an executive training program in Shanghai. Unlike most student 
samples, the participants represented potential customers of Chinese luxury brands. The majority of participants were employed in higher management positions; five were younger than 30 years, ten were between 30 and 40 years and three were older than 40 years; ten were female and eight male. Ten in-depth Chinese luxury brand cases were discussed with the participants (marked in Table 1). It was important to make them familiar with the brands because the awareness level of Chinese luxury brands is still relatively low even among luxury experts and experienced luxury consumers. As part of a questionnaire survey, participants were asked how Chinese they believe the ten luxury brands are (five-point scale) and why (open question); to rank the brands by their level of Chineseness, and to explain the criteria they used for the ranking. Participants were also asked their opinion about our pre-defined criteria. The survey was followed by an open discussion about the topic. Survey responses and documentary material were content-analyzed according to Mayring (2010).

\section{Results: Managing CoO Affiliations of Chinese Luxury Brands}

Results suggest six types of hybrid brand identities exist in the Chinese luxury segment which differ mainly by the degree to which these brands aim to be perceived as being 'Chinese' and/or 'cosmopolitan'. They include the following: (1) deeply and proudly Chinese brands such as NE Tiger; (2) Chinese brands eager for international fame (e.g. Seagull); (3) multi-cultural brands such as British-Chinese Mary Ching playing with the 'East meets West' philosophy; (4) foreign-owned brands such as Shang Xia which may fear to be perceived as being not authentically Chinese; (5) foreign-owned Chinese brands which seem quite open with their non-Chinese roots (e.g. Qeelin); and (6) cosmopolitan brands such as Charles Philip which feel inspired from Shanghai as a vibrant global hub, but are not mixing any Chinese elements into their identity. 
Fig 3. Managing Country-of-Origin affiliations for Chinese luxury brands

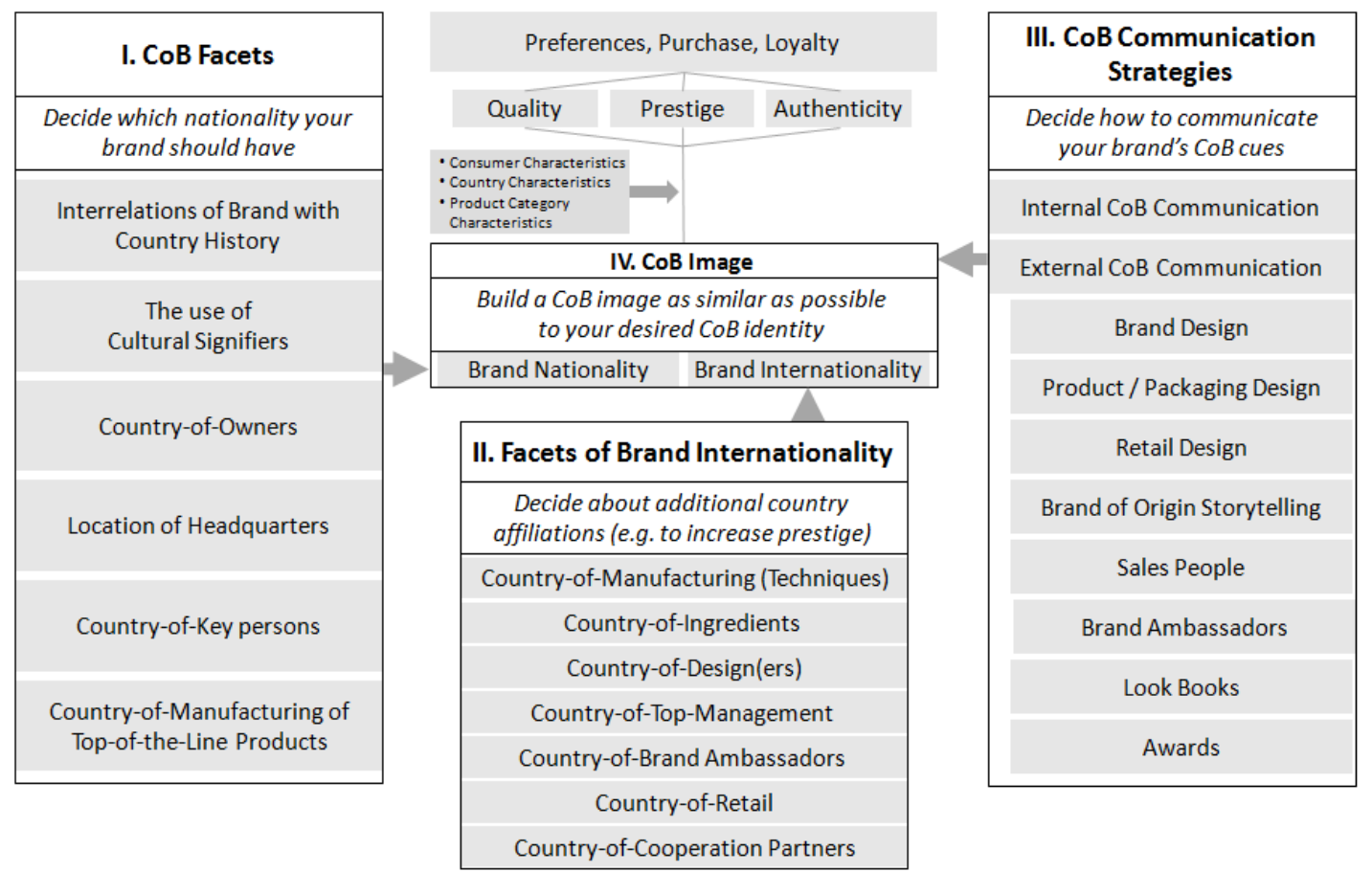

Figure 3 provides an overview of the resulting conceptual model for managing country-of-origin affiliations for Chinese luxury brands. First, brand managers must decide as to which nationality their brand should assume. For that purpose, they also need to understand the $\mathrm{CoB}$ facets that consumers use to decide how 'Chinese' a luxury brand is (we will discuss the identified CoB facets in section 6.1.). In addition, our research study found that Chinese luxury brands are making use of CoO-related strategies not only to communicate their $\mathrm{CoB}$ but also to improve their brand prestige. Therefore, brand managers need to decide whether and how to link their brand with additional country affiliations (we will outline facets of brand internationality in section 6.2.). This implies that marketers will need to consider how to communicate their CoB identity to their defined target groups (we will discuss typical CoB communication strategies in section 6.3.).

\subsection{CoB facets: how to position a luxury brand as being 'Chinese'}

It can be argued that $\mathrm{CoB}$ is a vital part of the brand identity and vision of Chinese luxury brands. Further, $\mathrm{CoB}$ is a primary source for the creation of symbolic consumer benefits, and for competitive differentiation. For instance, Jack Peng states his mission is to rival and exceed worldclass Western luxury brands; NE Tiger is positioned as the defender and inheritor of Chinese clothing culture and heritage, and BaYanKaLa claims to embody the rediscovery of Chinese wisdom. We found that respondents in the consumer survey use the following $\mathrm{CoB}$ facets to 
evaluate as to how 'Chinese' they perceive a luxury brand to be (in order of relevance). We will discuss each facet with supporting examples identified in the case study analysis.

- Interrelations of Brand with Country History. All respondents found this criterion very important (13) or important (5). If the history of a brand plays within the borders of the country and exhibits strong connections to the history of China, respondents are likely to perceive the brand as Chinese (c.f. Kipnis et al., 2012). Seagull, for instance, is perceived as very Chinese because of its strong ties to Chinese history; the company developed the first Chinese wristwatch in the 1950s. Shanghai Vive's brand revival strategy is a way to make the brand appear to have played a role in Chinese history, as an active contributor to Shanghai's glamorous Golden Twenties.

- Cultural Signifiers. Respondents pointed out that just adding 'Shanghai' to its brand name does not make Charles Philip a Chinese brand. Cultural signifiers do not only refer to visible representations, but generally to cultural meanings, values and practices (Wu et al., 2013). 'Terroir products' such as Changyu wine or other cultural products such as Jun porcelain represent specific Chinese regions and traditions. The respondents perceive cultural signifiers as almost as important as the first criterion for differentiating between Chinese and non-Chinese brand origin.

- Country-of-Owners. Ownership matters to Chinese consumers more than we expected; the majority of respondents found it very important (8) or important (5). To ensure a brand is seen as authentically Chinese, foreign investors may consider becoming (only) shareholders of a Chinese luxury business. For example, Italy's Illva Saronno group acquired about a third of the shares in Changyu, one of the oldest prestige wine brands in China. However, Shang Xia is clearly seen as a Chinese brand despite being owned by Hermès. Respondents explained that the founder, CEO and designer, Jiang Qiong Er is Chinese and is considered as the creative mind behind the brand. This demonstrates that a non-Chinese $\mathrm{CoO}$ cue may be 'healed' by other cues of Chineseness.

- Location of Headquarters. This criterion is seen as a necessary but not a pre-requisite condition for a Chinese luxury brand. For instance, respondents did not perceive China-based Charles Philip and Osiao as Chinese because of their inability to convey historical and cultural associations. Regional labeling is used as a strategy in order to establish a more favorable $\mathrm{CoB}$ perception. For instance, Charles Philip Shanghai and Shanghai Vive emphasize their Shanghainese origin to reduce possible negative connotations of luxury brands 'from China'. Chinese brands also try to make use of a more favorable 'country micro image' that may exist for certain competencies or product categories (Pappu et al., 2007). For instance, instead of 
highlighting any R\&D competencies, cosmetics brand BaYanKaLa claims that their products rely on ancient secrets of Chinese medicine.

- Country-of-Key Persons. This is also seen as an important criterion but to a lesser extent and with few respondents (2) perceiving it as unimportant. However, Qeelin, for instance, is not seen as truly Chinese by most respondents because it was founded by a French entrepreneur and later sold to the French luxury group, Kering.

- Country-of-Manufacturing of Top-of-the-Line Products. Luxury brands generally try to establish 'iconic products' such as the Kelly bag by Hermès. If the respondents evaluate a brand's origin by $\mathrm{CoM}$, they tend to refer only to these top-of-the-line products. However, this criterion was unimportant for the majority of respondents (10). This is proven in practice by SheJi-Sorgere which manufactures $100 \%$ of its products in Italy. On the other hand, emphasizing regional integration with local manufacturing and cooperation with local artisans can be a favorable approach for foreign-owned brands such as Shang Xia to strengthen their Chineseness. This is consistent with research by Kipnis et al. (2012) who argue that local manufacturing, support of local traditions, and a sense for regional well-being are critical elements to transform consumer perceptions of a brand from 'theirs' to 'ours'.

\subsection{Facets of brand internationality}

In addition to the brand's nationality, there are other elements in a brand's country designation that may be used to a firm's advantage (Chao, 1993). For Chinese luxury brands, the idea of brand internationality is to establish associations with foreign countries to the extent that this may help to increase brand prestige. Based on case study analysis and interviews with sales associates, we identified the following facets of brand internationality:

- Country-of-Manufacturing. There is evidence to suggest that the brand's rationale for the CoM decision is not based on production costs, but primarily on how it impacts its brand identity. In the same way as Rolex tries to seduce Chinese customers by playing the Swiss-made joker, Chinese jewelry and watch brands such as Qeelin are using Swiss-made manufacturing, turning foreign CoM into their advantage.

- Country-of-Manufacturing Techniques. Our research found that Chinese luxury ventures try to benefit from the image of country-specific manufacturing techniques which is somewhat similar to the country-of-engineering concept. For instance, Jack Peng states that their Chinese artisans learn shoemaking techniques in Italy. Similarly, Changyu and MPH highlight that they employ Italian machines and manufacturing techniques. However, some brands also use CoMT or similar facets to strengthen their Chinese CoB. For instance, Shanghai Tang reactivated 
legendary Shanghainese tailoring expertise with their 'Imperial Tailoring Collection' and NE Tiger uses old Chinese embroidery techniques.

- Country-of-Ingredients. Similar to CoM, brands such as Shanghai Vive communicate that their perfume flacons are made in France and 1436 Erdos emphasizes that their garments are made of Swiss cotton. To signal that they are not cosmopolitan, some brands underline their use of indigenous Chinese ingredients such as silk, cashmere, jade (Shanghai Tang) or herbs (BaYanKaLa).

- Country-of-Design(ers). Chinese luxury brands refer CoD as to the country where the designers come from. Many brands stress employing foreign designers (e.g. Sheme, She Ji-Sorgere), while brands set-up by Western companies place emphasis on the international mix and the Chinese members of their design teams (e.g. Qeelin).

- Country-of-Top Management. As the face of the brand, top managers have an impact on the brand's perceived internationality. We found that Qeelin sales associates are trained to underline the French founder's international socialite life (similar for Charles Philip); also Shang Xia communicates the CEO's international experience. On the other hand, BaYanKaLa does not miss pointing out that its French founder has lived in China for more than 20 years.

- Country-of-Brand Ambassadors. Brand internationality can also be achieved with foreign brand ambassadors and celebrities promoting the brand (e.g. Qeelin and Kate Winslet) or by referring to prominent foreign clients (e.g. NE Tiger states the Queen of Denmark being among the brand's high-profile customers).

- Country-of-Retail. A widespread strategy of Chinese luxury brands is to open retail outlets in Europe, most preferably in Paris (e.g. Shang Xia). The major purpose is not necessarily to generate sales, but to increase brand prestige, because European stores imply that the brand is desirable for European customers. Some brands also emphasize their presence at international trade fairs (e.g. Seagull) or running a design center in Europe (e.g. MPH).

- Country-of-Cooperation Partners. Another strategy includes establishing strategic alliances with favorable partners, for instance, between She-Ji-Sorgere and the Italian high-end manufacturer Caruso. The alliance between Shang Xia and Hermès includes cooperation in quality control, marketing and design. 
$\mathrm{CoB}$ is communicated especially by those areas of the marketing mix that are highly visible and which therefore can act as 'culture flags' (Chahal and Dutta, 2012). We identified the following $\mathrm{CoB}$ communication strategies that are applied by Chinese luxury brands:

- Brand design. CoB is expressed by the brand design especially with the brand name, logo and language and with national/cultural symbols (Kipnis et al., 2012). For instance, Qeelin expresses its strong Chinese identity with its brand name that refers to a Chinese national fruit. Jack Peng and Mary Ching combine their Chinese family names with their Western names. The brand colors and style of BaYanKaLa reflect the philosophy of Chinese ancient wisdom of healing and nurturing. To communicate brand internationality in its advertising campaigns, luxury car brand Hongqi portraits its L5 model in a European landscape.

- Product / packaging design. Naturally, products are a major communication tool of the CoB identity. Qeelin, for example, links most of its products to Chinese culture. The design philosophy behind Longio's white jade timepieces originates from phoenix mythology; symbolizing grace, luck and harmony in ancient China. Shuijinfang communicates its CoB identity with its packaging design showing scenic spots of its homeland Chengdu.

- Retail design. The choice and the design of retail outlets is another way to communicate a brand's CoB identity (Chahal and Dutta, 2012). Jack Peng, for instance, expresses his Eastmeets-West philosophy in its store design combining Chinese artefacts with a portrait of Louis XIV.

- Brand-of-origin storytelling. Storytelling is used to demonstrate interrelations between the brand's history and China. Charles Philip, for instance, communicates how his Shanghaiexperience with a street cobbler, who turned one of his shirts into a shoe, led to the creation of his brand. Qeelin communicates that its founder and the Chinese designer decided to set-up the Chinese jewelry brand together. This illustrates that brand storytelling can be used to influence the impact of a foreign founder on the $\mathrm{CoB}$ image.

- Sales associates. The actions of sales associates are a major communication channel for the $\mathrm{CoB}$ identity. At Shang Xia, sales associates explain in detail the Chinese origin of materials and details of Chinese craftsmanship which are conveyed as being integral to the brand's positioning. When we asked about the brand being owned by Hermès, the sales associate was emphatic in pointing out that: "They provide us with money, but we are an independent label". Charles Philip tries to overcome the problem of low Chinese CoM image by demonstrating the handmade manufacturing process of shoes in their showroom in Shanghai.

- Brand ambassadors and look books. Many luxury brands in China such as Qeelin and NE Tiger make use of 'look books' which are displayed in their stores to help customers to learn more 
about their brands; they also include pictures of foreign celebrities and other brand ambassadors wearing their products.

- Awards. Chinese brands tend to be particularly proud of international awards and recognition. The winemaker Changyu, for instance, emphasizes its inclusion in the list of the World's Most Admired Wines by the leading British magazine Drinks International.

\section{Discussion}

The findings of our research study suggest that the emergence of hybrid brands marks a new stage in the evolution of $\mathrm{CoO}$ research and is apparent within the Chinese luxury start-up segment (c.f. Phau and Prendergast, 2000). We complement the conceptualization of the CoB construct with reference to luxury brand-building in China. Significantly, the traditional approach of studying the effects of $\mathrm{CoO}$ information as extrinsic cues on product quality evaluation may no longer be adequate to fully understand $\mathrm{CoO}$ effects. Instead, we suggest to conceptualize CoB based on selfcongruity theory and as a component of brand identity. This implies a major shift from the current understanding of $\mathrm{CoB}$, to a more differentiated understanding (including actual / desired $\mathrm{CoB}$ identity / image). This is a prerequisite for further research on hybrid brands and can help preventing inconsistencies in CoO-related studies. Based on existing definitions of hybrid products (Chao, 1993), we defined hybrid brands and differentiated between various types of hybrid brands. Further, we were able to contribute to the research on $\mathrm{CoO}$ facets, and the relevance of the different $\mathrm{CoB}$ facets for Chinese luxury consumers. For instance, we added $\mathrm{CoO}$ facets that appear to be relevant for luxury brand-building in China, such as Country-of-Manufacturing Techniques. Based on literature analysis and empirical studies, we developed a conceptual model for managing $\mathrm{CoO}$ affiliations for hybrid brands within the context of Chinese luxury brands. In contrast to existing $\mathrm{CoO}$ research, we are turning the perspective from Western luxury brands (that may risk diminishing brand image with additional foreign $\mathrm{CoO}$ cues) to the perspective of Chinese luxury brands (that may have a chance of improving their brand image with additional foreign $\mathrm{CoO}$ cues).

Our research has theoretical implications also within the luxury brand management literature, for instance, with reference to the modes of luxury brand-building by Kapferer and Bastien (2012). The first mode reflects a European approach with an emphasis on long-established brand history; it is based on a hierarchic pyramid system in which the creator's vision is conveyed down the pyramid from unique pieces of haute couture to serial-produced pieces. The second mode represents an American approach to luxury in which the role of storytelling enables the brand to invent history of 
its own. In addition to the distinction between a European and American approach to luxury, we identified a hybrid approach specific to luxury brand-building in China.

As a result, our findings are relevant to managers of existing Chinese luxury brands and to Chinese and Western entrepreneurs and companies aiming to set-up Chinese luxury brands. Based on a decision about the type of brand they want to establish, our conceptual model provides guidance as to how to position a brand as more or less Chinese and how to strengthen brand prestige by linking a brand with additional (Western) $\mathrm{CoO}$ cues.

However, this study does not cover Chinese luxury consumers in general, but is limited to young professionals in first-tier cities. Although the small sample size limits the generalizability of the results, it allowed us to be certain that respondents know the brands well and to provide an opportunity to discuss the topic in-depth. Given that Chinese luxury brands are still a relatively new phenomenon, it is difficult to recruit participants with sufficient brand knowledge. The explorative nature of this study allowed us to develop an in-depth understanding of a new research phenomenon.

Future studies should enlarge the scope of the study to other consumer segments (e.g. to the premium / mass-market or concentrate on specific luxury consumer segments such as Millennials, the newly rich, the super-elite, etc.) and to other regions in China (e.g. second and third-tier cities or special administrative regions such as Macau). To study the impact of the consumer's age on $\mathrm{CoO}$ preferences is of particular relevance given the cultural variation toward luxury within different generations (Jiuan and Shan, 2018). Moreover, it is widely accepted that geographic differences influence consumer behavior as evident when comparing attitudes towards luxury consumption in tier 1 versus tier 3 cities (Atwal and Bryson, 2017). China is a pioneer in creating hybrid luxury brands outside the established luxury countries-of-origin. As this trend is likely to gain wider acceptance, future studies should test and complement the results for other emerging markets. 


\section{REFERENCES}

Ahmed S.A., D’Astous A., 2008. South East Asian consumer perceptions of countries of origin: the case of automobiles and videocassette recorders. Journal of Asia Pacific Marketing 1 (1), $19-41$.

Ahmed S.A., D’Astous A., 1993. Evaluation of Country-Of-Design and Country-Of-Assemble in a Multi-Cue/Multi-National Context. European Advances in Consumer Research 1, 214-221.

Arora, A.S., McIntyre, J.R., Wu, J., Arora, A., 2015. Consumer Response to Diffusion Brands and Luxury Brands: The Role of Country of Origin and Country of Manufacture. Journal of International Consumer Marketing 27 (1), 3-26.

Atwal, G., Bryson, D., 2017. Luxury Brands in China and India. Palgrave Macmillan, Basingstoke.

Balabanis, G., Diamantopoulos, A., 2008. Brand Origin Identification by Consumers: A Classification Perspective. Journal of International Marketing 16 (1), 39-71.

Belk, R.W., 1988. Possessions and the extended self. The Journal of Consumer Research 15 (2), 139-68.

Beverland, M., 2005. Crafting brand authenticity. Journal of Management Studies 42 (5), 10031029.

Bilkey, W.J., Nes, E., 1982. Country of origin effects on product evaluations. Journal of International Business Studies Spring/Summer, 89-99. doi: 0.1057/palgrave.jibs.8490539

Bloemer J., Brijs K., Kasper H., 2009. The CoO-ELM model: a theoretical framework for the cognitive processes underlying country of origin-effects. European Journal of Marketing 43 (1-2), 62-89. doi: 10.1108/03090560910923247

Chadha, R., Husband, P., 2006. The cult of the luxury brand: Inside Asia's love affair with luxury. Nicholas Brealey International, London.

Chahal, H., Dutta, K., 2012. Measuring Brand Strength: Concept and Mobile Handset Study. International Journal of Mobile Marketing 7 (3), 38-55.

Chao, P., 1993. Partitioning Country of Origin Effects: Consumer Valuations of a Hybrid Product. Journal of International Business Studies 24 (2), 291-306.

Charmaz, K., 2014. Constructing grounded theory (2nd ed.). Sage, Thousand Oaks.

Cheah, I., Zainol, Z., Phau, I., 2016. Conceptualizing Country-of-Ingredient Authenticity of Luxury Brands. Journal of Business Research 69 (12), 5819-5826.

Chevalier, M., Lu, P.X., 2010. Luxury China: market opportunities and potential. Wiley, Singapore.

Corbin, J., Strauss, A., 2008. Basics of qualitative research: techniques and procedures for developing grounded theory (4th ed.). Sage, Thousand Oaks.

Cordell, V.V., 1991. Competitive context and price as moderators of country-of-origin preferences. Journal of the Academy of Marketing Science 19 (2), 123-128. doi: 10.1007/BF02726004

Escalas, J.E., Bettman, J.R., 2005. Self-construal, reference groups, and brand meaning. Journal of Consumer Research 32, 378-389.

Fionda, A.M., Moore, C., 2008. The anatomy of the luxury fashion brand. Journal of Brand Management 16 (5/6), 347-363. doi: 10.1057/bm.2008.45

Fonrouge, C., Lipovetsky, G. (2013). Les entrepreneurs du luxe. International Management 17 (3), 31-35. doi: 10.2139/ssrn.2321102

Gao, L., Norton, M., Zhang, Z.M., To, C., 2009. Potential niche markets for luxury fashion goods in China. Journal of Fashion Marketing and Management 13 (4), 514-526. doi: 10.1108/13612020910991376

Gil, L.A., Kwon, K., Good, L.K., Johnson, L.W., 2012. Impact of Self on Attitudes toward Luxury Brands among Teens. Journal of Business Research 65 (10), 1425-1433.

Godart, F., Zhao, Y., 2014. Drivers of China's Desire for Luxury and Consequences for Luxury Brands. In: Atwal G., Bryson D. (eds) Luxury Brands in Emerging Markets. Palgrave Macmillan, Basingstoke. 
Godey, B., Pederzoli, D., Aiello, G., Donvito, R., Chan, P., Oh, H., Weitz, B., 2012. Brand and country-of-origin effect on consumers' decision to purchase luxury products. Journal of Business Research 65 (10), 1461-1470. doi: 10.1016/j.jbusres.2011.10.012

Godey, B., Pederzoli, D., Aiello, G., Donvito, R., Wiedmann, K., Hennigs, N., 2013. A crosscultural exploratory content analysis of the perception of luxury from six countries. Journal of Product \& Brand Management 22 (3), 229-237. doi: 10.1108/JPBM-02-2013-0254

Han, C.M., Terpstra V., 1988. The Role of Consumer Patriotism in the Choice of Domestic vs Foreign Products. Journal of Advertising Research 28 (3), 25-32.

Häubl, G., Elrod, T., 1999. The impact of congruity between brand name and country of production on consumers' product quality judgments. International Journal of Research in Marketing 16, 199-215. doi: 10.1016/S0167-8116(99)00011-7

He, H., Balmer, J.M.T., 2013. A grounded theory of the corporate identity and corporate strategy dynamic. European Journal of Marketing 47 (3), 401-430. doi: $10.1108 / 03090561311297391$

He, J., Wang, C.L., 2015. Cultural Identity and Consumer Ethnocentrism Impacts on Preference and Purchase of Domestic versus Import Brands: An Empirical Study in China. Journal of Business Research 68 (6), 1225-1233.

Heine, K., Petersen, F.E., 2015. Marketing Lessons Luxury Wine Brands Teach us About Authenticity and Prestige. The European Business Review Jan/Feb, http://www.europeanbusinessreview.com/marketing-lessons-luxury-wine-brands-teach-usabout-authenticity-and-prestige/

Heine, K., Phan, M., 2011. Trading-up mass-market goods to luxury products. Australasian Marketing Journal 19 (2), 108-114. doi: 10.1016/j.ausmj.2011.03.001

Hong, J.W., Zinkhan, G.M., 1995. Self-concept and advertising effectiveness: The influence of congruency, conspicuousness, and response mode. Psychology and Marketing 12, 53-77. doi: 10.1002/mar.4220120105

Hugstad, P., Durr, M., 1986. A Study of Country of Manufacturer Impact on Consumer Perceptions. In: Malhotra, N.K., Hawes, J. (eds) Developments in Marketing Science. Coral Academy of Marketing Science, Gables, FL, 115-119. doi: 10.1007/978-3-319-11101-8_24

Jiang, L., Shan, J., 2018. Heterogeneity of luxury value perception: a generational comparison in China. International Marketing Review 35 (3), 458-474. doi.org/10.1108/IMR-12-20150271

Johansson, J.K., Douglas, S.P., Nonaka, I., 1985. Assessing the impact of country of origin on product evaluations. Journal of Marketing Research 22, 388-96.

Jung, H.J., Lee, Y., Kim, H., Yang, H., 2014. Impacts of country images on luxury fashion brand: facilitating with the brand resonance model. Journal of Fashion Marketing and Management, 18 (2), 187-205. doi: 10.1108/JFMM-10-2013-0113

Juntunen, M., Saraniemi, S., Halttu, M., Tähtinen, J., 2010. Corporate brand-building in different stages of small business growth. Journal of Brand Management 18 (2), 115-133. doi: $10.1057 / \mathrm{bm} .2010 .34$

Kapferer, J.N., Bastien, V., 2012. The Luxury Strategy. Break the rules of marketing to build luxury brands. 2nd ed., Kogan Page, London.

Kapferer, J.N, 2012. The New Strategic Brand Management: Advanced Insights and Strategic Thinking. 5th. ed., Kogan Page, London.

Kim, S.W., 2008. The influence of country-of brand images on Korean consumers' brand evaluation: focusing on foreign luxury brands (Doctoral dissertation), The Graduate School of Korea University, Seoul.

Kipnis, E., Kubacki, K., Broderick, A.J., Siemieniako, D., Pisarenko, N.L., 2012. 'They don't want us to become them': Brand Local Integration and Consumer Ethnocentrism. Journal of Marketing Management 28 (7), 836-864.

Lee, D., Bae, S.W., 1999. Effects of Partitioned Country of Origin Information on Buyer Assessment of Binational Products. Advances in Consumer Research 26, 344-351. 
Liu, F., Li, J., Mizerski, D., Soh, H., 2012. Self-congruity, Brand Attitude,and Brand Loyalty: A Study on Luxury Brands. European Journal of Marketing 46 (7/8), 922-937.

Lu, P.X., 2008. Elite China: luxury consumer behaviour in China. Wiley, Hoboken.

Magnusson, P., Westjohn, S.A., Zdravkovic, S., 2011. "What? I thought Samsung was Japanese": Accurate or not, Perceived Country of Origin matters. International Marketing Review 28 (5), 497-507.

Manrai, L.A., Lascu, D.N., Manrai, A.K., 1998. Interactive effects on country of origin and product category on product evaluation. International Business Review 7 (6), 591-615. doi: 10.1016/S0969-5931(98)00026-2

Mayring, P., 2010. Qualitative Inhaltsanalyse: Grundlagen und Techniken. Beltz, Weinheim.

Melnyk, V., Klein, K., Völckner, F., 2012. The Double-Edged Sword of Foreign Brand Names for Companies from Emerging Countries. Journal of Marketing 76 (6), 21-37.

Miyazaki A. D., Grewal, D., Goodstein, R.C., 2005. The Effect of Multiple Extrinsic Cues on Quality Perceptions: A Matter of Consistency. Journal of Consumer Research 32 (1), 146153.

Mittal, B., 2006. I, Me, and Mine - How Products become Consumers' Extended Selves. Journal of Consumer Behaviour 5 (6), 550-562.

NDRC (2016). The $13^{\text {th }}$ Five Year Plan for Economic and Social Development of the People's Repubic of China. National Development and Reform Commission, http://en.ndrc.gov.cn/newsrelease/201612/P020161207645765233498.pdf.

O'Cass, A., Siahtiri, V., 2013. In Search of Status through Brands from Western and Asian Origins: Examining the changing Face of Fashion Clothing Consumption in Chinese young Adults, Journal of Retailing and Consumer Services 20 (6), 505-515.

Oetzel, J., Doh, J.P., 2009. MNEs and development: A review and reconceptualization. Journal of World Business 44, 108-120. doi: 10.1016/j.jwb.2008.05.001

Olson J.C., Jacoby J., 1972. Cue utilization in the quality perception process. In Venkatesan, M. (Ed.), SV - Proceedings of the Third Annual Conference of the Association for Consumer Research, Association for Consumer Research, Chicago, IL, 167-179.

Orbaiz, L.V., Papadopoulos, N., 2003. Toward a Model of Consumer Receptivity of Foreign and Domestic Products. Journal of International Consumer Marketing 15 (3), 101-126.

Pappu, R., Quester, P.G., Cooksey, R.W., 2007. Country Image and Consumer-based Brand Equity: Relationships and Implications for international Marketing. Journal of International Business Studies 38 (5), 726-745.

Phau, I., Prendergast, G., 2000. Conceptualizing the country of origin of brand. Journal of Marketing Communications 6 (3), 159-170. doi: 10.1080/13527260050118658

Piron, F., 2000. Consumer's perceptions of the country-of-origin effects on purchasing intentions of (in)conspicuous products. Journal of Consumer Marketing 17 (4), 308-321. doi: 10.1108/07363760010335330

Prendergast, G.P., Tsang, A.S.L., Chan, C.N.W., 2010. The interactive influence of country of origin of brand and product involvement on purchase intention. Journal of Consumer Marketing 27 (2), 180-188. doi: 10.1108/07363761011027277

Roth, M.S., Romeo, J.B., 1992. Matching product category and country image perceptions: A framework for managing country-of-origin effects. Journal of International Business Studies 64 (3), 477-497. doi: 10.1057/palgrave.jibs.8490276

Schooler, R.D., 1965. Product bias in the Central American common market. Journal of Marketing Research 2, 394-397. doi: 10.1002/tie.5060080211

Shukla, P., 2010. Status consumption in cross-national context: socio-psychological brand and situational antecedents. International Marketing Review 27, 108-129. doi:10.1108/02651331011020429

Sirgy, M.J., Lee, D.J, Johar, J.S., Tidwell, J., 2008. Effect of Self-Congruity with Sponsorship on Brand Loyalty. Journal of Business Research 61, 1091-1097. 
Tsai, W.S., Yoo, J.J., Lee, W-N., 2013. For Love of Country? Consumer Ethnocentrism in China, South Korea, and the United States. Journal of Global Marketing 26 (2), 98-114.

Usunier, J.-C., 1994. Social status and country-of-origin preferences. Journal of Marketing Management 10, 765-83. doi: 10.1080/0267257X.1994.9964320

Wall, M., Liefeld, J., Heslop, L.A., 1991. Impact of country-of-origin cues on consumer judgments in multi-cue situations: a covariance analysis. Journal of the Academy of Marketing Science 19 (2), 105-113. doi: 10.1007/BF02726002

Walley, K., Li, C., 2014. The market for luxury brands in China: Insight based on a study of consumer's perceptions in Beijing. Journal of Brand Management 22 (3), 246-260. doi: $10.1057 / \mathrm{bm} .2013 .29$

Ward, M.K., Dahl, D.W., 2014. Should Devil Sell Prada? Retail Rejection Increases Aspiring Consumers' Desire for the Brand. Journal of Consumer Research 41 (3), 590-609.

Wu, Z., Borgerson, J., Schroeder, J., 2013. From Chinese brand culture to global brands: insights from aesthetics, history and fashion. Palgrave Macmillan, Basingstoke.

Yasin, N.M., Noor, M.N., Mohamad, O., 2007. Does image of country-of-origin matter to brand equity? Journal of Product \& Brand Management 16 (1), 38-48. doi: $10.1108 / 10610420710731142$

Zhan, L., He, Y., 2012. Understanding luxury consumption in China. Journal of Business Research 65 (10), 1452-1460. doi: 10.1016/j.jbusres.2011.10.011 